\title{
APRENDIZAGEM BASEADA EM PROBLEMAS: UMA EXPERIÊNCIA NO ENSINO FUNDAMENTAL
}

\author{
ELI BOROCHOVICIUS ${ }^{1}$ \\ ORCID: https://orcid.org/0000-0003-1613-0961 \\ ELVIRA CRISTINA MARTINS TASSONI ${ }^{2}$ \\ ORCID: https://orcid.org/0000-0002-8968-3981
}

\begin{abstract}
RESUMO: A Aprendizagem Baseada em Problemas (ABP) é um método de ensino e aprendizagem que busca o desenvolvimento de conteúdos conceituais, procedimentais e atitudinais por meio de trabalhos colaborativos. O método pode ser aplicado em diferentes áreas do saber, e há prevalência de sua aplicação no Ensino Superior, com escassas pesquisas aplicadas ao Ensino Fundamental. Sobre o papel do professor, alguns autores defendem o docente como mediador importante na aprendizagem e outros lhe conferem um papel de coadjuvante. A ABP contribui para o desenvolvimento do pensamento crítico e reflexivo, promovendo uma aprendizagem significativa. Apresenta-se uma pesquisa qualitativa do tipo colaborativa, com o objetivo de identificar as mudanças na relação ensino e aprendizagem com a aplicação da ABP na disciplina de História do Ensino Fundamental de uma escola pública do interior de São Paulo. Os resultados mostraram que a ABP permite maior aproximação do professor com os alunos, potencializando a aprendizagem.
\end{abstract}

Palavras-chave: Aprendizagem Baseada em Problemas, ensino fundamental, formação de professor, metodologia ativa, processo de ensino e aprendizagem.

\section{PROBLEM-BASED LEARNING: AN EXPERIENCE IN SECONDARY SCHOOL}

\begin{abstract}
Problem-Based Learning (PBL) is a teaching and learning method that seeks to develop conceptual, procedural and attitudinal content through collaborative work. The method can be applied in different knowledge areas, and there is a prevalence of its application in Higher Education, with scarce research applied to Primary and Secondary Education. Regarding the role of the teacher, some authors defend the teacher as an important mediator in learning, while others confer a supporting role. PBL contributes to the development of critical and reflective thinking, promoting meaningful learning. Presented is the result of a collaborative qualitative research project. The objective of which was to identify changes in the teaching and learning relationship using PBL at a public secondary school in the interior of São Paulo through the subject of History. Overall, the results show that PBL allows the teacher to get closer to the students, enhancing learning.
\end{abstract}

\footnotetext{
${ }^{1}$ Pontifícia Universidade Católica de Campinas (PUC-Campinas). Campinas, SP, Brasil. <boro@boro.com.br>

2 Pontifícia Universidade Católica de Campinas (PUC-Campinas). Campinas, SP, Brasil. < cristinatassoni@puccampinas.edu.br>
} 
Keywords: Problem-Based Learning, secondary school, teacher training, active methodology, teaching and learning process.

\section{APRENDIZAJE BASADO EN PROBLEMAS: UNA EXPERIENCIA EN EDUCACIÓN PRIMARIA}

RESÚMEN: El Aprendizaje Basado en Problemas (ABP) es un método de enseñanza y aprendizaje que busca el desarrollo de contenidos conceptuales, de procedimiento y de actitud con trabajos de colaboración. La revisión de la literatura identificó que el método se puede aplicar en diferentes áreas de conocimiento y existe una prevalencia de su aplicación en la educación superior, con poca investigación aplicada a la educación primaria. Sobre el papel del maestro, algunos autores defienden como un mediador importante en el aprendizaje, y otros como un papel de apoyo. El ABP contribuya al desarrollo del pensamiento crítico y reflexivo, promoviendo un aprendizaje significativo. Se presenta una investigación colaborativa cualitativa, con el objetivo de identificar cambios en la relación de enseñanza y aprendizaje con la aplicación de ABP en la disciplina de Historia de una escuela primaria de una escuela pública en el interior de São Paulo. Los resultados mostraron que ABP le permite al maestro acercarse a los estudiantes, mejorando el aprendizaje.

Palabras clave: Aprendizaje Basado en Problemas, enseñanza primaria, formación del maestros, metodología activa, proceso de enseñanza y aprendizaje. 


\section{INTRODUÇÃO}

A Aprendizagem Baseada em Problemas (ABP), conhecida na língua inglesa por ProblemBased Learning (PBL), é um método de ensino e aprendizagem que nasceu em 1965 na escola de medicina de McMaster, na cidade de Hamilton, província de Ontário, no Canadá. O objetivo era ampliar o conhecimento e o desenvolvimento das habilidades médicas dos alunos em trabalho coletivo, cooperativo e colaborativo, partindo de situações-problema hipotéticas e próximas daquilo que os futuros médicos encontrariam em suas vidas profissionais.

Os educadores de McMaster entendiam que as aulas não estavam sendo eficazes na formação do aluno, dado que o conteúdo era amplamente esquecido, e, portanto, elas não garantiam aprendizagem. Em meio a questionamentos, críticas e planejamento, a primeira turma de estudantes, com 19 integrantes, foi iniciada com o uso do método em 1969 (SAVIN-BADEN; MAJOR, 2004).

Outros países, inclusive o Brasil, passaram a utilizar a ABP, majoritariamente no Ensino Superior e não apenas em cursos ligados às áreas médicas. Alguns professores americanos experimentaram a ABP no Ensino Fundamental, mas não foram encontradas pesquisas com o uso do método no Brasil nessa etapa de ensino, como poderá ser confirmado pela revisão de literatura apresentanda adiante. As publicações a respeito da ABP no Ensino Superior indicam que o método possibilita uma maior interação entre os alunos nos trabalhos em grupo e o estreitamento da relação entre professor e alunos, favorecendo o ensino e a aprendizagem. Dessa forma, questionou-se a possibilidade de se utilizar o método com o objetivo de identificar as mudanças na relação ensino e aprendizagem com a aplicação da ABP em uma disciplina do Ensino Fundamental de uma escola pública do interior de São Paulo. A pesquisa foi desenvolvida com quatro turmas de $7^{\circ}$. ano em uma escola pública, com a adesão voluntária de um professor de História, que se dispôs a aprender e a trabalhar com o método, planejando, em colaboração com o pesquisador, o seu uso em sala de aula.

Na percepção de Mamede (2001), a ABP foi originalmente concebida em uma estrutura de aprendizagem interdisciplinar, mas Kelson e Distlehorst (2000) entendem que existem muitas adaptações do método e que ele pode ser iniciado em uma única disciplina, motivada por um professor, sem o apoio institucional e sem todas as mudanças estruturais que o método sugere. No processo de ensino e de aprendizagem, a interdisciplinaridade tem o importante papel de estabelecer uma visão sistêmica do conhecimento, mas sua ausência não descaracteriza o método ABP, que tem por essência o uso de situações-problema, pesquisa, trabalho em grupo e moderação do professor.

Mamede (2001) ainda apresenta que o método foi idealizado em uma proposta de aprendizagem autodirigida, em que os alunos constroem o conhecimento a partir de um problema que deve ser estudado de forma colaborativa, e os estudantes formulam seus próprios objetivos de aprendizagem apropriando-se de um saber significativo. A aprendizagem autodirigida é utilizada somente em uma das fases da ABP; portanto, é necessário ressaltar que não se trata de um método de autoaprendizagem. Apesar de privilegiar muitas atividades centradas no aluno, este artigo desmitifica o conceito de autodireção do método, de forma a apresentar a relevância da mediação do professor em cada fase do processo, que inclui também o papel de se fazer o fechamento do assunto com a realização de sínteses de tudo que foi explorado e trabalhado, destacando-se os aspectos fundamentais do tema. Por meio de aulas dialogadas com os alunos, o professor faz uso de recursos e estratégias variadas, com o objetivo de sistematizar o que foi produzido ao longo do estudo. Ainda que não seja possível garantir a procedência pedagógica da $\mathrm{ABP}$, supõe-se que os princípios de aprendizagem que a norteiam trazem semelhança com as proposições dos filósofos John Dewey, que entende ser a experiência uma importante contribuição para o aprender, e Jerome Seymour Bruner, reconhecido por seus estudos experimentais sobre percepção, memória e pensamento (PENAFORTE, 2001; RIBEIRO, 2008; VEIGA, 2015).

Para Munhoz (2015), com o desenvolvimento da tecnologia e o forte crescimento das redes sociais, a ABP surge como uma nova forma de ensinar e aprender, contrapondo-se aos métodos tradicionais. Duarte (2010, p. 38), no entanto, considera as novas propostas educacionais como pedagogias negativas, dado que negam a educação tradicional, e critica a ideia de o aluno ser referência central para as atividades escolares, e o professor, mero "organizador de atividades que promove o que alguns chamam de negociação de significados construídos no cotidiano dos alunos".

Curiosamente, Savin-Bader e Major (2004) apresentam o papel do professor como sendo essencial para o método e afirmam que ele deve ter total controle sobre o conteúdo e o processo. $\mathrm{Na}$ 
visão de Masetto (2011), o professor colabora para que o aluno pesquise, conheça as fontes de informações, domine o caminho para acessá-las e aprenda a selecioná-las, compará-las, criticá-las e integrá-las ao seu mundo intelectual, mas não deixa de ser fonte de informações e de experiências práticas para o seu aluno. Professor e aluno são parceiros na construção do conhecimento, a empatia é fundamental e, por meio dela, abre-se o diálogo para que o professor conheça as dificuldades, a desmotivação e o desinteresse do aluno, assumindo uma atitude de mediação pedagógica. Park (2006) também entende que o papel do professor e a cooperação por meio de atividades em grupo são as duas das principais características da ABP.

As críticas ao uso da ABP em sala de aula surgem como em qualquer processo de construção de métodos e teorias educacionais e são históricas em relação às mudanças nos processos educacionais. De acordo com Saviani (2010), no Brasil, com a Proclamação da República em 1889, foi iniciada a reforma dos ensinos primário e secundário, que pretendeu conciliar os estudos literários com os científicos - e essa reforma foi amplamente criticada. Em 1932, foi publicado nos principais jornais brasileiros "O Manifesto dos Pioneiros da Educação Nova", e a sua recepção foi polêmica e também muito criticada. Em 1947, foi constituída uma comissão para elaborar a Lei de Diretrizes e Bases (LDB), promulgada no fim do ano de 1961. Seus membros pertenciam a uma corrente pedagógica humanista moderna, representada pelos Pioneiros da Educação Nova, e a orientação de caráter descentralizador do ensino prevaleceu, mantendo-se a autonomia dos estados. A década de 1960 foi palco de intensa experimentação educativa, predominando a concepção pedagógica renovadora. Em 1964, o Brasil passou por um momento político conturbado quando ascendeu o regime militar, que buscava desenvolvimento econômico com uma pedagogia tecnicista, inspirada nos princípios de racionalidade, eficiência e produtividade, pedagogia que foi também muito criticada, especialmente na década seguinte. A década de 1980 foi marcada pela busca de teorias que contrapusessem a pedagogia tecnicista e foi caracterizada por uma ampliação na produção acadêmico-científica. Na década de 1990, o construtivismo tornou-se referência tanto para as reformas de ensino em diversos países quanto para as práticas escolares no Brasil, e sua ênfase deslocou-se dos resultados para o processo, sendo amplamente criticado por parcela significativa dos estudiosos da área. Assim, parece fazer parte do movimento de mudanças que o método também seja criticado; no entanto, algumas críticas desconsideram a possibilidade de flexibilidade em sua aplicação, que contempla adequações às particularidades de cada espaço social. Diante da complexidade do fenômeno educativo, não se trata de aplicação teórica na prática, mas da articulação teoria e prática. Nesse sentido, refletir sobre os princípios essenciais da $\mathrm{APB}$ - problematização, pesquisa e sistematização das informações - dinamiza a ação educativa em sala de aula e pode proporcionar a construção e a apropriação de conhecimentos de maneira mais profícua, gerando aprendizagem.

A aprendizagem implica resultados, processos e condições, admitindo grande variedade em cada um destes componentes, e as suas diversas combinações proporcionam diferentes situações de aprendizagem (POZO, 2002). Para Nérici (1993), aprendizagem significa apropriar-se de algo que ainda não esteja incorporado ao comportamento do indivíduo, resultante do seu envolvimento em uma determinada situação, tanto devendo produzir mudanças duradouras, como também aquilo que foi aprendido deve ser utilizado em diferentes contextos.

Para Godoy (2000), as escolas têm utilizado frequentemente aulas expositivas, ainda que dialogadas, voltadas para a transmissão de conhecimentos, e o conteúdo a ser aprendido tem sido apresentado, pelos professores aos alunos, em sua forma final, privando-os, muitas vezes, do exercício das habilidades intelectuais mais complexas, como a aplicação, a análise, a síntese e o julgamento.

Em 2014, o Plano Nacional de Educação (PNE) refirmou a necessidade de estabelecer diretrizes pedagógicas para a Educação Básica e de criar uma base nacional que orientasse os currículos do País. Assim nasceu a Base Nacional Comum Curricular (BNCC), um documento de caráter normativo que define as aprendizagens essenciais para os alunos da Educação Básica, assegurando a construção de algumas competências, dentre elas:

Exercitar a curiosidade intelectual e recorrer à abordagem própria das ciências, incluindo a investigação, a reflexão, a análise crítica, a imaginação e a criatividade, para investigar causas, elaborar e testar hipóteses, formular e resolver problemas e criar soluções (inclusive tecnológicas) com base nos conhecimentos das diferentes áreas (BRASIL, 2018, p. 9). 
A BNCC está organizada por competências a serem desenvolvidas em diferentes âmbitos competências gerais para a Educação Básica, competências específicas de cada área de conhecimento e competências específicas referentes a cada componente curricular - e também por habilidades a serem desenvolvidas por meio dos objetos de conhecimento (os conteúdos). Essa organização traz de volta a discussão de um currículo por competências e, como consequência, o debate a respeito de atitudes, de valores e, sobretudo, daquilo que os alunos devem "saber fazer". Considera-se, nesse contexto, que o "saber fazer" não é necessariamente uma retomada do tecnicismo, mas pode significar um processo de aprendizagem que contextualiza os conhecimentos aprendidos em situações concretas de uso, visando uma formação integral e o pleno exercício da cidadania.

É nesse contexto que se entende que a ABP possa se apresentar como uma das possibilidades para esse novo momento educacional. Ela surgiu para ampliar o conhecimento e o desenvolvimento das habilidades dos alunos e servir como uma alternativa às aulas que não estavam se mostrando eficazes na formação dos alunos. Trata-se, portanto, de um movimento em busca de caminhos para o enfrentamento das dificuldades encontradas na relação ensino e aprendizagem, mas não pode ser considerada uma solução definitiva para todas as questões escolares, especialmente em razão das suas variáveis e complexidades.

Considera-se que o processo de aprendizagem envolve a apropriação de informação e de conhecimentos, bem como o desenvolvimento de habilidades para estabelecer novas relações, para obter novas referências para interpretar o mundo em que se vive, fazendo uso de tais informações e conhecimentos.

Para Ribeiro (2008), a ABP surge como uma alternativa para a construção do conhecimento, dado tratar-se de uma metodologia de ensino e aprendizagem em que um problema é utilizado como início de discussão de um conceito ou conteúdo, com direcionamento do professor daquilo que é produzido pelos alunos em pequenos grupos, motivando-os a pesquisar. Uma grande parte das aprendizagens ocorre em contextos de interação social, determinando a direção e o significado do que se aprende. A colaboração promove o desejo de aprender e beneficia os alunos com certas dificuldades, sem prejuízo para os mais experientes. Colaborando, surgem melhores perguntas e melhores respostas em função da ajuda mútua, da construção conjunta de novos argumentos e de ideias que não surgiriam individualmente (POZO, 2002). A interação entre os discentes favorece a aquisição de conhecimentos e incrementa a qualidade das aprendizagens. Alguns exemplos disso são a melhor capacidade de negociar em busca de acordos que satisfaçam as partes envolvidas, a facilidade de comunicação e a ajuda mútua (BONALS, 2003).

A sociedade contemporânea impõe um olhar inovador e inclusivo para a promoção de redes de aprendizagem colaborativa, que, segundo Duch, Groh e Allen (2001), é uma característica essencial da ABP e que pode ajudar os alunos a se tornarem mais articulados, autônomos e com habilidades para se relacionarem socialmente. Para Oliveira (2010), os procedimentos metodológicos que permitem a aprendizagem ativa preconizam a participação de docentes e discentes na relação de ensino e aprendizagem, com o objetivo de formar agentes ativos da sociedade, que saibam identificar os problemas e buscar soluções plausíveis.

A ideia de trabalhar com a ABP, no entanto, muitas vezes evoca reações hostis, e Boud e Feletti (1999) sugerem que a possibilidade de resistência com o uso do método se dá pela ansiedade dos educadores na obtenção de bons resultados, que nem sempre são imediatamente alcançados, assim como pelo desconforto devido ao rompimento com os padrões existentes, causando medo pelas mudanças que o método prevê.

Outra preocupação constante dos professores que começam a trabalhar com a ABP tem relação com o comportamento dos alunos quando estão trabalhando em grupos, pressupondo-se que aproveitam a atividade para se socializarem. No entanto, professores experientes no método relatam que essas preocupações tendem a ser infundadas e o uso da ABP ainda elimina alguns problemas de comportamento, pois muitos deles ocorrem quando o aluno está entediado, distraído e desinteressado (LAMBROS, 2004).

Apesar de a ABP ter nascido na área da saúde e ser voltada para o Ensino Superior, Ribeiro (2008) considera que seus princípios possibilitam o uso em outras áreas do conhecimento e sua utilização se mostra viável também para o Ensino Básico. Na década de 1990, a Samford University foi pioneira 
no uso da ABP na área de artes e humanidades, e a Academia de Ciências e Matemática de Illinois (IMSA), que atende estudantes com talentos em matemática e ciências, envolveu-se com a ABP e estabeleceu o Centro de Aprendizagem Baseada em Problemas no ano de 1992, o qual serve como um laboratório educacional de ABP. Nesse sentido, existe um interesse crescente no método para aplicação no Ensino Básico, mas são poucas as pesquisas relatadas com experiências que não sejam em Ensino Superior (SAVIN-BADEN; MAJOR, 2008).

Barell (1998) aponta que muitos professores nos Estados Unidos já desafiaram seus alunos a experimentarem estratégias de ensino e aprendizagem baseadas na ABP. Alunos da $3^{a}$. série da Bradford Elementary School em Upper Montclair foram levados a refletir sobre questões como: Por que os raios solares vêm do espaço? Por que os ônibus são pintados de amarelo? Como as pessoas se vestiam há milhares de anos? Alunos da $6^{a}$. série da Solomon Schecter School of Bergan Country de New Milford utilizaram um dos elementos básicos da ABP para promover a investigação, gerar suas próprias questões e relatar suas descobertas sobre a formação de montanhas. Estudantes da $10^{a}$. série da Dumont High School em Dumont pesquisaram e levantaram hipóteses sobre a formação de bactérias; os alunos da $12^{a}$. série da Jefferson Township High School, em Oakridge, estudaram os candidatos à presidência na aula de ciência política; e os alunos da $12^{a}$. série de química da James Caldwell High School, em Caldwell, estudaram se deveria ser aprovada ou não a construção de uma usina nuclear em sua comunidade.

Com o objetivo de identificar as obras relacionadas ao uso da ABP no Ensino Fundamental, a investigação teve início com uma revisão de literatura realizada em três fontes: artigos científicos internacionais e nacionais, teses e dissertações nacionais e livros internacionais e nacionais. Considerando que a pesquisa se deu em ambiente escolar, buscaram-se artigos, teses e dissertações que continham a palavra "PBL" em qualquer campo e a palavra escola no resumo. Optou-se por utilizar a sigla PBL em inglês, pois o método é mundialmente reconhecido pela sigla em inglês e os resumos publicados no Brasil geralmente são apresentados também na língua inglesa. Para a busca na base de dados internacional, foi utilizada a palavra school, pois o Ensino Fundamental pode aparecer como Elementary School, Primary School, Middle School ou Secondary School, mas sempre aparecendo a palavra school. Para os livros internacionais, buscaram-se títulos que continham a sigla PBL, e para os livros nacionais, as buscas foram realizadas por títulos contendo a expressão "Problem-Based Learning", com hífem, "Problem Based Learning", sem hífem, "Aprendizagem Baseada em Problemas" e contendo as siglas PBL e ABP.

$\mathrm{Na}$ base de dados internacional Science Direct, a busca retornou 37 artigos e, pela leitura dos resumos, foram selecionados nove artigos. Os demais versavam sobre Aprendizagem Baseada em Projetos, Aprendizagem com Base em Problemas Assistidos por Computador, ou não mencionavam explicitamente o uso da ABP. Foi possível observar maior incidência da aplicação do método em disciplinas como física e matemática em cursos de graduação na África e na Ásia. Os artigos apresentaram que o método é eficaz especialmente no que tange à habilidade de comunicação, trabalho em grupo e raciocínio. É interessante observar que, nos artigos que buscaram comparar o uso do método ABP em sala de aula com o método dito usual, se concluiu que os alunos se sentiram mais motivados com os estudos, e as habilidades de raciocínio e o desenvolvimento conceitual foram superiores nas turmas com a ABP. Os artigos não apresentaram o papel do professor no processo e não trouxeram a perspectiva docente, dado que o foco das investigações estava no método, e não necessariamente nas possibilidades e desafios que o método proporciona para a relação ensino e aprendizagem.

Já na base de dados nacional, Scientific Electronic Library Online (SciELO-Brasil), a busca retornou cinco artigos. Foi possível identificar que todos os artigos se referem a experiências com o Ensino Superior e, em sua maioria, relacionadas à área médica. Em geral, a ABP foi descrita como um método importante para o estreitamento da relação docente e discente, possibilitando melhor aproveitamento na relação de ensino e aprendizagem, embora não seja uma solução definitiva para todas as questões educacionais. O professor passa a desenvolver um papel importante de colaboração com os grupos de alunos e, pela imprevisibilidade dos questionamentos, pode se sentir acuado caso não esteja adequadamente preparado para a intensa interação que ocorre em razão do método. No entanto, a possibilidade do surgimento de dúvidas não previstas pelo professor acaba propiciando a promoção do seu aprimoramento profissional. É preciso destacar que a aproximação com o professor, potencializada pela ABP, também é fator de menor sofrimento do aluno, uma vez que ele se sente mais seguro com a sua aprendizagem. 
A busca na Biblioteca Digital Brasileira de Teses e Dissertações (BDTD) retornou 13 trabalhos, sendo 3 teses e 10 dissertações. Nos trabalhos científicos, foi possível identificar que as pesquisas no Brasil sobre a ABP ainda são incipientes e a maior incidência de estudos se dá com alunos predominantemente adultos. Dois trabalhos foram desenvolvidos no Ensino Médio e um com alunos da Educação de Jovens e Adultos (EJA). Não foram encontradas pesquisas no Brasil com o uso da ABP no Ensino Fundamental. É interessante observar que um dos estudos identificou que o método propiciou maior interação entre alunos e professores, favorecendo a relação de ensino e aprendizagem, mas que a implantação e o desenvolvimento precisam ser adaptados à realidade de cada escola.

Em biblioteca virtual americana, foram encontrados 213 livros sobre a ABP, sendo que 95 faziam menção à ABP (88 deles estavam em inglês, 6 em alemão e 1 em espanhol). Os demais faziam referência ao Project Based Learning, ou não faziam referência explícita à ABP. Analisando os títulos dos livros, havia 15 que faziam menção à área médica, em que nasceu a ABP. A pesquisa ainda retornou sete livros com menção ao Ensino Superior, cinco contendo informações do Ensino Básico (Ensino Fundamental e Ensino Médio) e apenas quatro livros traziam no título o Ensino Fundamental. Esses quatro livros foram analisados e mostram que, apesar de a ABP ter sido criada para o Ensino Superior, é possível também aplicá-la no Ensino Básico e que, embora o método seja usado em poucas escolas, os resultados iniciais são encorajadores e apresentam eficácia. Os autores destacam a importância do professor no processo, especialmente na criação das situações-problema e nos questionamentos metacognitivos, visando contribuir para o desenvolvimento de um pensamento crítico e reflexivo nos alunos, tornando a aprendizagem mais significativa.

No Brasil, foram encontrados e analisados seis livros. Identificou-se que se discute o uso da ABP em diferentes áreas do saber, como administração, contabilidade e medicina, mas sempre no Ensino Superior. Foram encontradas experiências no Brasil com alunos de Graduação e Pós-Graduação em Engenharia. Ribeiro (2008) aborda os fundamentos, a caracterização e o processo do método, incluindo o papel do professor e dos alunos. Para o autor, um dos grandes desafios do método está na mudança da natureza do trabalho do professor, que deve escolher e criar situações-problema abertas para que os alunos possam desenvolver atividades colaborativas, bem como desenvolver orientação e interagir com o aluno no nível metacognitivo, questionando o seu raciocínio superficial e suas noções vagas e equivocadas. Como vantagem, apresenta que a ABP "favorece a aquisição de conhecimentos de forma mais significativa e duradoura" e, como desvantagem, a "imprecisão no conhecimento das teorias mais avançadas" (RIBEIRO, 2008, p.41).

Araújo e Sastre (2009) organizaram uma obra apresentando experiências com a ABP em Aalborg (Dinamarca), em Maastricht (Holanda), em Valld'Hebron, Barcelona (Espanha) e um projeto acadêmico da USP Leste, em São Paulo, Brasil. Os resultados iniciais do projeto demonstram o envolvimento dos alunos com o estudo e a qualidade do conhecimento produzido.

Martins e Espejo (2015) apresentaram relatos de três experiências com o uso do método. A primeira foi em Cingapura, na instituição educacional Republic Polytechnic; a segunda experiência foi na Escola de Artes, Ciências e Humanidades da Universidade de São Paulo (USP), que apresentou vantagens no uso do método por causa das possibilidades que cria no trabalho colaborativo. A terceira experiência foi na Faculdade de Economia, Administração e Contabilidade da USP. Um dos professores relata que o sistema de aulas, tal como vinha acontecendo, estava se esgotando, e era necessário transformar a disciplina em algo mais prático. A questão é que o professor precisa se adaptar ao método que o estimula a trabalhar com o inesperado, um caminho desafiador. A integração da teoria com a prática é destacada como a principal vantagem, assim como a possibilidade dos professores também trabalharem em parceria.

Veiga (2015) reúne resultados com o uso do método em quatro instituições de ensino, cujos nomes não foram mencionados. Identificou-se que a ABP é uma alternativa pedagógica que rompe com a lógica linear, acabada e transmissiva do conhecimento, estimula a participação ativa dos alunos com integração dos conhecimentos e estimula a formação continuada. É uma forma mais humanizada e dinâmica de ensinar, e o maior desafio do método está no professor, sendo necessária a promoção de formação continuada aos docentes.

Foi observada uma diferença em relação ao papel do professor. Há autores, como Tomaz (2001) e Ribeiro (2005), que valorizam e defendem o professor como mediador importante na 
aprendizagem, enfatizando a relevância do trabalho docente para o desenvolvimento do aluno; por outro lado, Munhoz (2015) explicita o papel do professor como coadjuvante no processo de aprendizagem, que deve ser autodirigido pelo estudante, o que acaba por fortalecer algumas críticas, como as elaboradas por Duarte (2010).

A revisão de literatura permitiu conhecer a produção acerca do método, e foi possível inferir que existe carência de obras relatando o uso da ABP no Ensino Fundamental. Tal escassez motivou a realização da pesquisa, que objetivou identificar as mudanças na relação ensino e aprendizagem com a aplicação do método ABP em uma disciplina do Ensino Fundamental de uma escola pública municipal de uma cidade no interior do estado de São Paulo.

Apoiando-se em Barrel (1998), acredita-se que o uso do método envolve considerações importantes, tais como a cultura escolar voltada para a pesquisa, o grau de comprometimento dos envolvidos com os princípios do método, os recursos e o tempo disponíveis e a habilidade e maturidade dos estudantes para trabalharem de forma colaborativa. Esses aspectos são relevantes para potencializar o engajamento tanto de professores como de alunos na produção de conhecimento, no interior da escola.

\section{METODOLOGIA}

Tratou-se de uma pesquisa colaborativa com abordagem qualitativa. Teve como procedimentos para a produção do material empírico a observação do local, dos sujeitos e dos materiais, o ato de ouvir o professor participante, de conhecer suas preocupações, o seu trabalho, bem como a investigação de suas percepções sobre o uso do método.

Conhecer os sentimentos do docente participante foi importante, motivo pelo qual foram utilizadas as entrevistas e narrativas como parte dos instrumentos de pesquisa; mas era necessário também conhecer os resultados na perspectiva dos alunos. Devido à grande quantidade de sujeitos, optou-se pela aplicação de questionários.

Para Ibiapina (2016), a pesquisa colaborativa é recente, já que as investigações construídas nessa perspectiva surgem a partir da década de 1980 com a organização de conhecimentos gerada a partir da participação dos integrantes que agem colaborativamente.

De acordo com a autora, foram identificadas três correntes para a definição da gênese da pesquisa colaborativa. A primeira aponta para a construção de conhecimento científico colaborativo entre pesquisadores e professores, surgindo como uma alternativa teórico-metodológica de desenvolvimento da pesquisa-ação, quando organizada com intencionalidade colaborativa. Nesse caso, geralmente é classificada como pesquisa-ação colaborativa ou investigação-ação colaborativa. A segunda corrente está na perspectiva da investigação em rede e das comunidades de prática, assumindo que a pesquisa deve ser construída por pesquisadores e professores desde a elaboração do problema até a análise e apresentação dos resultados. A terceira corrente defende que a pesquisa colaborativa se baseia nos princípios orientadores de investigação em uma perspectiva crítica e perde o vínculo com a epistemologia da pesquisa-ação. Sugere que os professores possam participar da problematização, organização e produção, mas não necessariamente dos três movimentos e na mesma intensidade do pesquisador. A interação, no entanto, é necessária para a produção de conhecimentos sobre as práticas educativas orientadas pela reflexão crítica, em que os processos reflexivos são necessariamente colaborativos.

Oliveira (2017) entende que a colaboração é um movimento de interação mútua, em um intercâmbio de ideias e pensamentos em relacionamento sem hierarquia, gerando interdependência dos participantes do grupo na realização das tarefas.

Para Ibiapina (2008), pesquisar colaborativamente na área de educação é investigar um objeto de pesquisa proposto por um pesquisador a um professor motivado a refletir sobre a sua própria prática. Isso significa que o professor não é o sujeito pesquisado, mas partícipe e coprodutor da pesquisa, estabelecendo interações das suas competências com as do pesquisador em busca da transformação do contexto da escola e da sociedade em que estão inseridos. A pesquisa colaborativa exige o envolvimento de professores da escola em projetos que enfrentem o desafio de mudar as práticas escolares e de contribuir para o desenvolvimento de seus participantes. É uma oportunidade para que os professores participem como coprodutores da investigação, sem necessariamente se tornarem pesquisadores. 
Os encontros entre pesquisador e participantes são parte do processo da pesquisa colaborativa, a qual Oliveira (2017) entende ser o momento em que o pesquisador socializa os objetivos e questões da investigação, buscando a adesão volitiva do grupo.

A pesquisa colaborativa apresenta três condições essenciais na perspectiva de Ibiapina e Bandeira (2017): 1) os participantes não necessariamente têm as mesmas funções nas tomadas de decisões durante a pesquisa; 2) as negociações podem se dar ao longo da pesquisa, dependendo da necessidade de cada situação; 3) o envolvimento dá-se na possibilidade de ocorrência de compartilhamento de significados. Assim, as relações constituem-se de forma ativa, por meio da linguagem crítica dos participantes.

$\mathrm{Na}$ pesquisa colaborativa, o "pesquisador e participantes tornam-se parceiros no processo de pesquisa", portanto, o que determina a pesquisa colaborativa é o envolvimento dos participantes, as decisões conjuntas e as interpretações e reflexões construídas por meio de discussões coletivas (BANDEIRA, 2016 p. 70).

De acordo com as obras consultadas, entende-se que a pesquisa colaborativa precisa necessariamente atender a quatro premissas básicas: 1) ser realizada de forma coletiva; 2) os participantes devem ser voluntários; 3) todas as vozes devem ser ouvidas; 4) os resultados precisam ser discutidos.

A investigação aqui apresentada é caracterizada como pesquisa colaborativa, pois partiu da necessidade de um professor voluntário, apesar de iniciada por intenção do pesquisador, visando investigar aspectos da prática educativa. $\mathrm{O}$ formato em que as aulas aconteciam causava desmotivação, desinteresse, indisciplina e pouco envolvimento por parte dos alunos, motivo pelo qual o professor vislumbrou a possibilidade de modificar esse cenário com o uso da ABP. No segundo semestre do ano de 2017, o professor realizou três observações de aulas do pesquisador no Ensino Superior, possibilitando discussões a respeito daquilo que fora observado e reflexões sobre as possibilidades que o método ofereceria para as aulas de História. Diversos encontros foram realizados com o objetivo de criar os materiais que seriam utilizados pelos alunos em 2018, assim como para discutir, em momentos recorrentes, sobre as necessidades de alterações que surgiram ao longo do processo, antes de serem implantadas. Os resultados foram analisados de forma conjunta, e o professor teve a oportunidade de se manifestar quanto à redação final.

O conjunto de instrumentos pode ser assim descrito: 1) análise documental, a exemplo do currículo da Rede Municipal de Ensino, materiais produzidos de forma colaborativa (pesquisador e professor) e utilizados como recurso didático-pedagógico pelo professor, relatórios produzidos pelos alunos durante a aplicação do método e notas finais disponibilizadas pela Unidade Escolar; 2) entrevista inicial com o professor responsável para identificar o seu conhecimento prévio sobre o método, entrevista intermediária visando identificar os aspectos positivos, negativos e as mudanças necessárias para o segundo semestre letivo, e entrevista final para conhecer suas impressões a respeito do método ABP desenvolvido no ano letivo; 3) narrativas do professor colaborador, colhidas ao longo do processo, com o intuito de identificar o andamento dos trabalhos por meio de seu olhar crítico-reflexivo; 4) observação das salas de aula, para verificar como o método estava sendo empregado e discutir com o professor possíveis mudanças em busca de otimização dos resultados, sem a descaracterização da ABP; 5) questionários com alunos ao fim do ano letivo para saber quais mudanças foram sentidas na relação com o professor em sala de aula e suas percepções quanto ao conhecimento adquirido.

Para a realização da pesquisa, foi necessária a anuência da Secretaria Municipal de Educação, a autorização da Unidade Escolar, a aprovação do projeto em Reunião Pedagógica e um professor voluntário. Recebidas todas as autorizações e tendo a aprovação do Comitê de Ética em Pesquisa, foram iniciadas as visitas à escola. Foi voluntário o professor da disciplina de História, com licenciatura (2008) e bacharelado (2009) em História. O interesse por fazer pesquisa levou-o a ingressar em um programa de pós-graduação, defendendo sua dissertação de mestrado em 2013. Com a expansão da rede federal de ensino técnico, o professor vislumbrou a possibilidade de ingressar na carreira docente. Em busca de experiência no magistério, prestou concursos para redes municipais e iniciou a carreira docente em 2015. No ano seguinte, foi transferido para a escola em que se realizou a investigação. Embora a intenção inicial do professor fosse obter experiência em sala de aula para pleitear o magistério federal, sentiu-se instigado pelo Ensino Fundamental, sobretudo, quanto às abordagens didáticas e pedagógicas voltadas para o público adolescente. A partir de suas experiências iniciais, o professor vem desenvolvendo reflexões 
sobre a educação formal nessa etapa de ensino, o que o levou a demonstrar interesse nesta pesquisa e se voluntariar como sujeito participante.

Com o objetivo de planejar as aulas, que seguem processos com etapas e relatórios definidos, era necessário conhecer o currículo para que fossem criadas, de forma colaborativa, as situaçõesproblema, contemplando o conteúdo previsto pela Rede Municipal de Ensino. A situação-problema pode ser um texto, figura, tabela, quadro, gráfico ou qualquer outra informação, criada pelo docente, que é utilizada como ponto de partida no uso do método.

Nos objetivos da disciplina de História, consta no currículo que, a partir da problematização das relações sociais, deve haver uma interação de forma crítica e ética com a realidade, tendo os conhecimentos históricos como parâmetro para se perceberem as transformações e se reconhecerem, nos diferentes contextos históricos, as ações políticas, as instituições sociais, a economia e a cultura. Como a ABP parte de uma situação-problema, está consonante com os objetivos curriculares. Foi a partir do currículo que o professor e o pesquisador elaboraram um cronograma de trabalho, para a criação de situações-problema que levassem os alunos a conhecerem a Antiguidade Ocidental, a Alta Idade Média, o Islamismo e a Baixa Idade Média. Foi necessário um esforço de estudo desse período histórico por parte do pesquisador antes de serem iniciadas as discussões com o professor.

As situações-problema, criadas pelo professor e discutidas com o pesquisador antes de serem apresentadas aos alunos, são documentos que iniciam o processo de aprendizagem. Para que fosse possível desenvolver as situações-problema, pesquisador e professor concordaram que seria necessário partir da questão "O que meus alunos devem saber?" e dos conhecimentos e habilidades que os alunos devem desenvolver, de acordo com o currículo produzido pela Secretaria Municipal de Educação.

Em posse da situação-problema, apresentada de maneira contextualizada em forma de texto escrito e imagens, os alunos, individualmente, liam e anotavam as suas percepções e compreensões para, posteriormente, discutirem com o seu grupo. Essa discussão acontecia oralmente, mas eram depois registradas, ainda em grupo, em um documento específico denominado Relatório Parcial, que era corrigido pelo professor e servia de guia para que os alunos, individualmente, realizassem pesquisas em busca de informações relacionadas a cada situação-problema. Esse momento contava com a orientação e a mediação intensas feitas pelo professor. Após reunir as informações pesquisadas, os alunos elaboravam, em grupo, um resumo organizando os conhecimento aprendidos, em um documento denominado Relatório Final. Os resultados que compunham esse Relatório eram apresentados oralmente por um ou mais alunos convidados pelo professor e debatidos com todos os demais alunos da sala. Após esse processo, um aluno de cada grupo realizava uma auto-avaliação e uma avaliação dos seus pares (dos outros componentes do grupo) em um documento denominado Relatório do Líder. Os grupos de trabalho foram formados pelo professor, e os seus participantes tinham como tarefa escolher um líder para cada situação-problema, com base em critérios estabelecidos livremente, ou seja, cada grupo poderia selecionar os critérios que considerasse relevantes para aquele momento. Preferencialmente, os grupos indicavam um líder para cada situação-problema, oportunizando essa experiência para vários colegas. Encerrando o ciclo da situação-problema, o professor fazia um fechamento do conteúdo explorado, por meio de uma aula dialogada, exercícios ou outra estratégia que pudesse servir como sistematização e consolidação dos conteúdos e conceitos desenvolvidos durante todo o trabalho.

Para conhecer a familiaridade do professor com o método e suas expectativas, optou-se por uma entrevista inicial. Para que fosse possível identificar as necessidades que surgiram durante o semestre letivo e propor soluções, fez-se uma entrevista com o professor durante o processo. E, finalmente, para se conhecerem as possibilidades e desafios que o método proporcionou ao professor e quais as suas percepções em relação à ABP ao término do ano letivo, foi realizada uma entrevista final. As entrevistas foram videogravadas, pois o vídeo traz a vantagem de permitir que se ouça o entrevistado e se percebam as suas expressões faciais e movimentações corporais, garantindo melhor qualidade na análise dos dados. Posteriormente, as entrevistas foram transcritas para que pudessem ser analisadas não apenas mediante áudio e vídeo, mas também na forma textual.

Dado que o professor foi o responsável pela aplicação do método em sala de aula e o objetivo geral da pesquisa foi analisar as mudanças na relação ensino e aprendizagem com a aplicação do método ABP em uma disciplina do Ensino Fundamental de uma escola pública, as narrativas do docente foram um instrumento metodológico importante para o desenvolvimento da investigação, já que está 
fortemente inserida nos estudos do campo educacional por possibilitar a compreensão das práticas pedagógicas, bem como as motivações e escolhas humanas, consideradas as suas complexidades.

Para que as informações chegassem até o pesquisador, optou-se por utilizar mensagens eletrônicas. Algumas vezes, foram narrativas enviadas por correio eletrônico; e muitas vezes, foram encaminhados textos curtos em mensagens instantâneas por aplicativo de celular, que permitiam a exteriorização do que o professor estava sentindo naquele momento específico. As trocas de mensagens também serviram para marcar encontros, resolver questões administrativas, trocar informações técnicas a respeito do método e dialogar sobre o andamento da pesquisa.

O aplicativo de celular também permite o uso de áudios, imagens e vídeos, mas ficou combinado entre as partes que seriam usados exclusivamente textos quando o assunto fosse relacionado à pesquisa, para facilitar a análise, e em casos mais administrativos, como o agendamento de reuniões, áudios poderiam ser trocados, o que aconteceu com pouca frequência.

Além das narrativas do professor, optou-se pelo uso da observação como instrumento metodológico para se conhecer o ambiente escolar, verificar a infraestrutura que a escola dispunha para o desenvolvimento da ABP, perceber as reações dos alunos no desenvolvimento das etapas do método, a exemplo da forma como organizavam a sala de aula e como estavam desenvolvendo os relatórios, pesquisas e avaliações.

Para a pesquisa, foram feitas diversas observações, em diferentes datas, com dois principais objetivos: 1) conhecer os ambientes gerais da escola e a infraestrutura disponível, como salão de entrada, sala de apoio, sala de direção, secretaria, sala dos professores, banheiros, biblioteca, estacionamento, salas de aula, cozinha e quadra de esportes; 2) perceber o desenvolvimento das etapas do processo e a forma como os alunos organizavam a sala de aula.

As narrativas e entrevistas foram utilizadas para se conhecer a percepção do professor sobre o uso da ABP. A observação permitiu que o pesquisador pudesse acompanhar o desenvolvimento do método em sala de aula, mas a voz dos alunos também precisava ser analisada. Dessa forma, optou-se por utilizar o questionário como instrumento metodológico para se conhecerem os sentimentos dos alunos em relação à ABP. O questionário foi aplicado no fim do ano de 2018, após a divulgação das notas finais, e era composto por 11 questões de múltipla escolha, com apenas três alternativas cada. $\mathrm{O}$ objetivo da redução do número de alternativas foi tornar o questionário mais apropriado à idade dos respondentes, de modo a reduzir a possibilidade de interpretação equivocada e contribuir para que o instrumento fosse respondido de forma completa. Além das questões, foi disponibilizado um espaço para que o aluno pudesse fazer qualquer comentário a respeito do método vivenciado por eles ao longo do ano.

\section{A ABP NO ENSINO FUNDAMENTAL}

A Unidade Escolar onde foi realizada a investigação está localizada na região mais populosa do município, possui 22 salas de aula divididas em quatro blocos, sendo três delas com lousa digital, para atender a 17 turmas no período matutino, 15 no vespertino e 14 no noturno. Possui uma quadra poliesportiva coberta, utilizada nas aulas de Educação Física, e os demais espaços são destinados às atividades administrativas, como sala de direção, apoio, secretaria e almoxarifado. A biblioteca dispõe de poucos livros didáticos, paradidáticos, atlas e revistas. A escola não oferece laboratório de informática, indispensável para o acesso a um acervo bibliográfico digital, a uma consulta em páginas eletrônicas e com possibilidade de elaboração de relatório e material visual para a apresentação, procedimentos fundamentais no método ABP. Não existem equipamentos tecnológicos simples na maioria das salas de aula, como projetor e caixa de som, que possibilitem ao professor e aos alunos o uso de recursos didáticos diversos. As salas são pouco ventiladas e o seu estado de conservação é precário. Em algumas delas, não há porta, o que dificulta a acústica, prejudicando a atenção dos alunos, que frequentemente é interrompida por ocorrências externas A sala dos professores é pequena, pouco convidativa ao convívio, possui duas mesas grandes, cadeiras antigas, não padronizadas, armários de metal ao fundo, com muitas portas amassadas, outras quebradas e diversos objetos espalhados sobre eles, criando poluição visual.

Observou-se que a infraestrutura da escola confirma o que Luckesi (2011) já destacou em relação às condições de ensino no Brasil. Geralmente são perversas, com quantidade excessiva de alunos em sala de aula, material pedagógico inadequado, bibliotecas insatisfatórias, baixos salários dos 
professores e espaços físicos insatisfatórios. A escassez de recursos tecnológicos reduz as possibilidades de pesquisa e diminui consideravelmente as condições para o bom desenvolvimento do método, no entanto, não o impossibilita, já que os alunos têm à disposição livros didáticos, ainda que em quantidade limitada.

O professor trabalhou durante o ano com turmas de $6^{\circ}$. e $7^{\circ}$. anos do Ensino Fundamental, nos períodos matutino e vespertino, e optou por aplicar o método ABP apenas com as turmas de $7^{\circ}$. ano, nos dois períodos. Em um primeiro momento, a intenção era desenvolver a pesquisa em apenas uma turma, mas o professor decidiu aplicar o método com todas as suas quatro turmas de $7^{\circ}$. ano.

A maioria dos alunos tem entre 12 e 13 anos de idade, pertence a famílias de baixa renda, e $76 \%$ deles estão cursando o $7^{\circ}$. ano em idade escolar correta. Foram 116 alunos participantes, distribuídos em quatro turmas, sendo 26 alunos na Turma Um, 34 alunos na Turma Dois, 29 alunos na Turma Três e 27 alunos na Turma Quatro.

As situações-problema e os modelos iniciais de relatórios que seriam utilizados pelos alunos - o Relatório Parcial e o de Avaliação do Líder e dos Pares -, bem como os critérios para avaliação das etapas de cada situação-problema, foram criados, sempre de forma colaborativa com o pesquisador. Além de todo o planejamento, o professor também acompanhou todo o processo, fez um fechamento abordando os principais pontos a serem compreendidos, trouxe novidades não pesquisadas pelos alunos e fez a devolução corrigida dos relatórios utilizados e uma avaliação individual para compor a nota final dos alunos.

Os trabalhos com uso do método ABP foram desenvolvidos pelos alunos seguindo quatro importantes passos: 1) fizeram individualmente a leitura da situação-problema proposta pelo professor, discutiram a situação-problema em grupo e apresentaram ao professor o Relatório Parcial para ser corrigido; 2) com base na correção do Relatório Parcial realizada pelo professor, fizeram pesquisa no material didático disponibilizado em sala de aula, com possibilidade de estenderem as pesquisas fora do ambiente escolar, e apresentaram em grupo o Relatório Final por escrito sobre o que aprenderam; 3) fizeram uma apresentação oral criando possibilidades de discussão sobre os temas abordados em debate; 4) líderes fizeram avaliação do processo.

Os grupos eram heterogêneos, formados aleatoriamente pelo professor, e foram modificados em uma única oportunidade, antes do início do segundo semestre. De acordo com Lourenço e Palma (2005), a heterogeneidade de um grupo possibilita troca de experiências, argumentações, informações e choques com diferentes pontos de vista, permitindo que as situações de conflito cognitivo contribuam para a formação do educando. Os alunos que costumam se dedicar aos estudos geralmente apresentam aversão por trabalhar com um colega com rendimento escolar mais baixo, comportamento pouco adequado e que relativiza a importância dos conhecimentos para a sua formação. O depoimento do professor, no entanto, demonstrou que, em alguns casos, houve percepção de uma boa interação.

Dado que os alunos estariam trabalhando com a ABP pela primeira vez, o professor e o pesquisador entenderam que seria interessante aplicar uma situação-problema teste e desenvolver todas as etapas do método para que os alunos se familiarizassem com os formulários e com a nova forma de trabalho em sala de aula. Cogitou-se aplicar uma situação-problema com conteúdo atualizado e multidisciplinar, mas ficou decidido que seria mais produtivo relembrar o conteúdo da disciplina ensinado ao término do ano anterior. Assim, foi construída uma situação-problema teste relacionada ao tempo e aos tipos de calendário, contendo textos e imagens com espaços para os alunos preencherem e algumas perguntas simples. Como Relatório Final, foi sugerida a elaboração de um texto curto, contendo respostas para as diversas questões relacionadas à situação-problema. Para a pesquisa, foram disponibilizados os livros didáticos usados no ano anterior. Por limitação de tempo, os alunos não fizeram a apresentação e o preenchimento do Relatório do Líder.

A partir daí, intencionava-se aplicar as etapas do método, com duas situações-problema no primeiro bimestre e três situações-problema nos outros três bimestres; mas o professor optou por não utilizar a ABP no quarto bimestre em razão da grande quantidade de atividades escolares que interromperiam a sequência de aulas, já previstas no calendário escolar.

A primeira situação-problema tinha por objetivo localizar a cidade de Roma no mapa mundial, identificar a época em que foi fundada e os elementos da vida na Roma antiga. Os alunos precisavam dizer que Roma foi fundada em 753 a.C., século VIII a.C., que se desenvolveu até o século 
V, que faz parte da Península Itálica, estando próxima dos povos gregos e egípcios, já estudados anteriormente. Deveriam identificar imperadores, governantes, gladiadores e práticas como comércio, construção, arquitetura, agricultura, bem como conhecer a mitologia romana, a exemplo da lenda da fundação da cidade.

Alguns cuidados devem ser tomados para a criação da situação-problema. Wood (2003) alerta que os problemas devem ser apropriados ao nível de compreensão dos alunos, devem ser convidativos e interessantes, com informações que estimulem a discussão e incentivem a busca por explicações para as questões apresentadas e que promovam a participação na busca de conhecimento. Dessa forma, a primeira situação-problema trouxe o mapa atual da Itália, um texto apresentando como o país é atualmente, com alguns dados interessantes, uma foto do Coliseu de Roma, questionando-se sobre a construção - o que remeteria os alunos ao passado histórico -, o escudo do time de futebol Associazone Sportiva Roma, que traz a Lupa Capitolina, uma loba amamentando os místicos fundadores gêmeos de Roma, Rômulo e Remo, e uma foto de um jogador de futebol brasileiro. Além do escudo do time de futebol e a foto do jogador, a situação-problema apresentou um texto curto com questões históricas do clube e o que representava o seu escudo.

Houve uma dificuldade inicial, sobretudo com a leitura, pois o texto era, para os alunos, muito extenso, dispersando-os na atividade. Ler não implica decodificar símbolos escritos, mas, sim, extrair o significado e dar sentido adequado ao texto lido. Envolve o reconhecimento das palavras, habilidades linguísticas gerais, memória, inferência e o desenvolvimento da expressão clara e organizada de ideias (ANDRADE; CELESTE; ALVES, 2019).

As necessidades de aprimoramento de leitura por parte dos alunos continuaram presentes na segunda situação-problema; dessa forma, optou-se por modificar a situação-problema três, adotandose nova estratégia. Foi preparado um grande mapa contendo sete números e, abaixo dele, sete figuras com textos curtos, que deveriam ser numerados, fazendo-se a correspondência com os números do mapa. O objetivo era identificar os territórios em torno do Mar Mediterrâneo entre os séculos VIII a.C. e III e conhecer as expansões territoriais, dominação política, as Guerras Púnicas e a integração comercial. Mesmo com textos mais curtos, o desinteresse pela leitura de um material escrito era quase unânime. Embora existissem alguns alunos com mais proatividade, foi necessário um esforço do professor realizando uma leitura coletiva.

A situação-problema quatro continha um cartum que demandava análise e interpretação, com certo grau de complexidade. Os alunos acabaram se atendo a detalhes menores e não direcionando o olhar para as coisas mais importantes. O semestre foi encerrado com a situação-problema cinco, tratando das mudanças na Europa Ocidental após a queda de Roma. Foi apresentado um texto e quatro imagens de vestígios arqueológicos de civilizações da Idade Média, cada uma encontrada em um continente diferente.

O primeiro semestre foi um período de muito aprendizado, de erros e acertos, promovendo satisfação com a possibilidade de serem criadas novas situações-problema mais próximas da realidade daquela escola. Para o segundo semestre, optou-se por continuar com a criação de situações-problema que envolvessem o aluno. Para a situação-problema seis, foi disponibilizado um texto curto sobre o feudalismo, com duas figuras que objetivavam mostrar as diferenças das classes sociais da Alta Idade Média e da atualidade. Percebe-se uma preocupação nítida em trazer a história para o presente, em apresentar um significado para os alunos compreenderem a realidade histórica.

A situação-problema sete trouxe um texto sobre a Peste Negra, com explicações de como a bactéria Yersinia Pestis se proliferou na Ásia e chegou à Europa; e a situação-problema oito apresentou o conteúdo ligado à Civilização Árabe e as Cruzadas.

O Relatório Parcial é a ferramenta utilizada para o cumprimento da segunda etapa do processo e compreende a necessidade de os alunos definirem o problema, identificarem os conceitos a serem estudados, analisarem o problema, estruturarem e sintetizarem propostas de pesquisa, assim como definirem os objetivos de aprendizagem. O objetivo desse relatório é ajudar os alunos a destacarem os assuntos mais importantes que a situação-problema traz e facilitar o plano de estudos. Foi criado um modelo inicial de relatório com quatro campos para que os alunos preenchessem, em grupo, as informações relacionadas ao problema e ao trabalho em grupo. Esse modelo foi utilizado apenas nas três primeiras situações-problema, depois o modelo foi repensado e alterado. 
O primeiro Relatório Parcial cumpriu o seu papel ao fazer com que a investigação fosse instigante e ao ter provocado debate entre os alunos. O primeiro campo do relatório propunha a identificação - no texto da situação-problema - dos aspectos que os alunos julgavam serem os mais relevantes. A maioria dos grupos preencheu com uma grande quantidade de frases, alguns grupos escreveram pouco, e apenas um grupo deixou o campo sem preenchimento na situação-problema três. O segundo campo propunha a identificação dos pontos principais da situação-problema, mas os alunos anotavam, com poucas palavras, aquilo que mais gostavam do texto. O terceiro campo objetivava que os alunos identificassem os tópicos mais importantes para servir de base para a construção do texto do Relatório Final, mas alguns grupos elaboraram perguntas, e outros deixaram o campo sem preenchimento.

O último campo servia para que o professor discutisse com os alunos os conteúdos conceituais que deveriam ser pesquisados, explicitasse aos alunos os possíveis equívocos e que fosse apresentada uma estrutura para a construção do Relatório Final.

Em função dos relatos do professor que apontavam as necessidades dos alunos, procurouse fazer uma revisão no Relatório Parcial e criar um modelo novo, mais adequado à realidade daqueles alunos, sem perder a essência da proposta do relatório: apresentar os resultados da discussão do grupo e ser norteador das pesquisas no livro didático.

O novo Relatório Parcial continha um quadro com espaços para os alunos identificarem, na situação-problema, a época, o lugar, os sujeitos, o que faziam, como e por quê. O objetivo principal era gerar discussão sobre o momento histórico que estava sendo estudado. Também foram inseridas diversas frases para os alunos informarem se cada uma das afirmações era verdadeira ou falsa. O objetivo era tornar a leitura mais dinâmica e interessante para os estudantes, exigindo que buscassem na situaçãoproblema a resposta que gerasse discussão no grupo e permitisse apropriação das informações contidas no texto da situação-problema para o desenvolvimento da pesquisa. O Relatório passou a servir como um guia de leitura, e os alunos se viram motivados a ler, compreender e discutir a situação-problema. $\mathrm{O}$ movimento de mudança na postura dos alunos pode ter relação com as novas propostas do Relatório Parcial, mas é preciso considerar que o professor também sentiu que havia um processo de familiarização com a nova forma de trabalhar, e assim foram surgindo novas estratégias para o desenvolvimento do Relatório.

O Relatório Final é a ferramenta utilizada para o cumprimento da terceira etapa do processo, que pode ser a produção de um texto com os resultados das pesquisas, eventualmente a solução de exercícios propostos pelo professor ou qualquer outro produto final elaborado pelos alunos após pesquisa e discussão sobre o tema no grupo. Para a pesquisa, optou-se por receber dos alunos um texto aberto, demandando que apresentassem aquilo que puderam aprender com as suas pesquisas e discussões dentro dos grupos. O objetivo do Relatório é tornar os alunos mais autônomos, capazes de realizar pesquisas nas mais variadas fontes de informação, fazendo com que o grupo possa apresentar um relatório consensual com os novos conceitos aprendidos.

Para que os alunos possam realizar as suas pesquisas, é necessário ter um ambiente propício e material bibliográfico. A escola, entretanto, não dispunha de laboratório de informática para que os alunos pudessem pesquisar na internet, sua biblioteca era muito pequena, não comportando a quantidade de alunos de uma turma em seu interior, e o acervo era reduzido, mas dispunha de alguns livros didáticos que poderiam ser emprestados aos alunos, de forma que o professor disponibilizava dois livros didáticos por grupo. Durante as pesquisas, o professor relatou que a proximidade com os alunos permitiu identificar uma série de limitações com a leitura e com a compreensão de texto, além de dificuldades para formulação das questões apropriadas que resultassem nas respostas adequadas ao que se almejava.

Como não havia computadores na escola, a proposta para os primeiros relatórios finais era a produção de um texto manuscrito, com uma estrutura básica de introdução, desenvolvimento e conclusão, mas o resultado geral não foi positivo. Os alunos apresentavam textos com poucos parágrafos, às vezes, desconexos, demonstrando a necessidade do desenvolvimento de habilidades de organização de ideias e de conhecimento de elementos textuais para a produção de textos mais estruturados e completos. Da mesma forma que o Relatório Parcial demandou reflexão sobre a sua efetividade, o Relatório Final também precisou ser repensado e reorganizado. O texto livre deu espaço a um exercício que geralmente continha três perguntas abertas, exigindo pesquisa no material didático para as respostas, 
em textos curtos. Além disso, foi inserido um exercício com afirmativas para os alunos dizerem se eram verdadeiras ou falsas.

Os resultados começaram a se mostrar positivos, pois houve maior participação e interação dos grupos. Infere-se que os textos curtos e direcionados à situação-problema estavam mais adequados ao que os alunos conseguiam entregar. As mudanças propostas não descaracterizam o método, pois o principal objetivo do Relatório Final é a apresentação dos resultados da pesquisa. De acordo com os bons resultados apresentados, sugere-se, para as situações-problema iniciais, que os relatórios sejam mais direcionados, com perguntas mais focadas e trazendo atividades que envolvam os alunos com a leitura. À medida que os estudantes se mostrem mais seguros, os relatórios podem ganhar complexidade até que sejam exigidos textos abertos.

A apresentação dos resultados encontrados pelos alunos cumpre a quarta etapa do processo e tem por objetivo a socialização dos conhecimentos adquiridos com a pesquisa, embasados na bibliografia. Essa etapa permite o desenvolvimento de conteúdos atitudinais como as habilidades de organização de ideias, a comunicação, o respeito ao próximo e o aprimoramento da linguagem oral, corporal e visual. A exposição oral traz oportunidades de aprendizagem tanto para o expositor quanto para o seu público, pois, ao expor o conteúdo, o aluno precisa utilizar marcadores discursivos que garantam a inteligibilidade da mensagem, sustentando a coesão das estruturas e a coerência temática, enriquecendo seu repertório linguístico. O público terá acesso às descobertas do expositor e poderá refletir e aprender com elas (SCHNEUWLY; DOLZ, 2013).

Para que os alunos pudessem se preparar para uma boa apresentação, seria desejável que tivessem acesso a recursos tecnológicos simples como um computador com programa de apresentação e projetor na sala de aula, mas infelizmente a disponibilidade dos recursos era limitada. Coube então aos alunos se apresentarem sem absolutamente nenhum recurso que os ajudasse, tornando a atividade entediante e exaustiva.

O Relatório do Líder é desenvolvido na quinta etapa do processo. O documento é utilizado para o desenvolvimento de autoavaliação e avaliação dos pares, realizada por um aluno escolhido pelo grupo no início de cada situação-problema, acompanhado do professor, com o objetivo de identificar os equívocos encontrados durante a realização de todas as tarefas de cada uma das situações-problema e fazer com que o grupo reflita, se reorganize e sugira estratégias para a superação das possíveis lacunas existentes.

Os critérios, criados de forma colaborativa entre professor e pesquisador, para a avaliação dos líderes foram: 1) participação nas discussões dentro e fora da sala de aula; 2) respeito pelas opiniões de outros membros do grupo; 3) contribuição para o consenso e organização; 4) realização das tarefas.

O aluno escolhido como líder reunia-se com o professor e atribuía uma nota para cada membro do grupo, incluindo a si mesmo, para cada um dos quatro critérios mencionados anteriormente, bem como uma nota final, considerando a média das notas individuais. Além disso, deveria preencher quatro quadros pequenos, informando: 1) como contribuiu para o desempenho do grupo; 2) o que poderia melhorar; 3) quais os desafios que surgiram e como buscaram a superação; 4) como foi a postura ética de cada aluno dentro do grupo. Esses campos não valiam nota e tinham a intenção de fazer o aluno refletir sobre a sua postura e a de cada membro da equipe, compreendendo a importância do trabalho individual para o sucesso do grupo. Para Sá (2001 p. 198), "a identificação pelo próprio aluno de lacunas na sua base de conhecimentos potencializa o resultado final da experiência de aprendizagem na ABP".

Essa foi a primeira oportunidade que os alunos tiveram de realizar uma autoavaliação na escola. O professor reuniu os líderes em torno dele, em horário de aula, explicou sobre a importância e os objetivos daquela avaliação e esteve próximo para ajudá-los com dúvidas que poderiam surgir. Em observação, foi possível identificar que, antes de os alunos iniciarem o preenchimento de cada um dos quadros, refletiam, pensavam; infere-se que ponderavam antes de exteriorizarem suas avaliações para o papel.

O fechamento do professor é o momento em que o docente pode ministrar uma aula expositiva, dialogada, ou ainda praticar exercícios com o objetivo de aprofundar os conceitos mais relevantes, destacar os pontos principais da situação-problema e apresentar aos alunos curiosidades sobre o tema. Esta é a sexta e última etapa do processo. As aulas haviam sido planejadas e preparadas com recursos audiovisuais, contendo fotos, ilustrações, mapas e, em algumas oportunidades, vídeos. O 
professor situava os alunos no contexto histórico, mostrava figuras e lançava perguntas relacionando o momento histórico com a atualidade, trazendo conceitos e uma série de curiosidades, promovendo uma aula interativa, interessante e divertida.

Para a avaliação, cada situação-problema tinha as notas computadas, conforme demonstrado no Quadro abaixo:

Quadro 1: Valor das notas das situações-problema

\begin{tabular}{cr} 
& Valor \\
\hline Relatório Parcial & $\mathbf{2 , 0 0}$ \\
Organização & 0,50 \\
Leitura & 0,50 \\
Registro & 0,50 \\
Envolvimento & 0,50 \\
\hline Relatório Final & $\mathbf{4 , 0 0}$ \\
Conceitos & 2,00 \\
Aparência e Caligrafia & 0,40 \\
Estrutura de Texto e Sintaxe & 0,40 \\
Ortografia & 0,40 \\
Argumento e hipóteses & 0,40 \\
Novidade e curiosidade & 0,40 \\
\hline Apresentação & $\mathbf{4 , 0 0}$ \\
Oralidade & 1,20 \\
Respeito pela fala do outro & 1,20 \\
Participação da turma & 1,20 \\
Compartilhamento & 0,40 \\
\hline TOTAL & $\mathbf{1 0 , 0 0}$
\end{tabular}

Fonte: Elaborada por Borochovicius e Tassoni (2020)

Destaca-se que o professor corrigia os relatórios, participava das apresentações e, para cada situação-problema, apresentava as notas aos grupos, com os seus comentários e dando condições para que os alunos pudessem compreender a razão das notas e tivessem oportunidade de reverem seus erros e aperfeiçoarem os relatórios das próximas situações-problema.

As notas do Relatório Parcial e do Relatório Final eram endereçadas para cada grupo, mas a nota da Apresentação era única para toda a sala. O objetivo da nota única é estimular o debate em sala de aula, e não responsabilizar apenas os apresentadores pelas qualidades das apresentações. Ao fim de cada bimestre, era realizada a média aritmética de todas as notas das situações-problema realizadas naquele período.

O modelo de nota da autoavaliação do líder e dos pares pode ser observado no Quadro abaixo. 
Quadro 2: Modelo de notas do Relatório do Líder

\begin{tabular}{|l|c|c|c|l|l}
\cline { 2 - 6 } \multicolumn{1}{c|}{} & $\begin{array}{c}\text { Participação } \\
\text { nas discussões } \\
\text { dentro e fora } \\
\text { da sala de aula }\end{array}$ & $\begin{array}{c}\text { Respeito pelas } \\
\text { opiniões de } \\
\text { outros } \\
\text { membros do } \\
\text { grupo }\end{array}$ & $\begin{array}{c}\text { Contribuição } \\
\text { para o } \\
\text { consenso e } \\
\text { organização }\end{array}$ & $\begin{array}{c}\text { Realização das } \\
\text { tarefas }\end{array}$ & NOTA FINAL \\
\hline Líder & & & & & \\
\hline Membro 1 & & & & & \\
\hline Membro 2 & & & & & \\
\hline Membro 3 & & & & & \\
\hline
\end{tabular}

Fonte: Elaborada por Borochovicius e Tassoni (2020)

$\mathrm{Na}$ autoavaliação do líder e avaliação dos pares da situação-problema um, foram analisados nove relatórios. A média das notas dos líderes em autoavaliação foi 8.28, sendo que um deles atribuiu a si mesmo nota 6.0. Na avaliação dos pares, os alunos não pouparam seus colegas, tendo aparecido notas 0, 0.5, 1.0, 2.0, 3.0, 4.0, 5.0 e 5.5. De 29 notas, 11 foram abaixo de 6.0, representando 37,93\%.

\begin{tabular}{|c|c|c|c|c|c|c|c|c|}
\hline & \multicolumn{8}{|c|}{ Quadro 3: Notas das avaliações de líderes } \\
\hline & \multicolumn{8}{|c|}{ Situação-problema } \\
\hline & 1 & 2 & 3 & 4 & 5 & 6 & 7 & 8 \\
\hline Relatórios analisados & 9 & 9 & 23 & 17 & 23 & 23 & 22 & 17 \\
\hline Média dos Líderes & 8,28 & 7,67 & 9,04 & 8,74 & 9,23 & 9,20 & 9,15 & 9,29 \\
\hline Quantidade de notas dos pares & 29 & 28 & 83 & 68 & 87 & 87 & 82 & 65 \\
\hline Notas abaixo de 6,0 & 11 & 4 & 19 & 16 & 20 & 23 & 22 & 13 \\
\hline$\%$ de notas abaixo de 6,0 & $37,93 \%$ & $14,29 \%$ & $22,89 \%$ & $23,53 \%$ & $22,99 \%$ & $26,44 \%$ & $26,83 \%$ & $20,00 \%$ \\
\hline
\end{tabular}

O quadro acima apresenta os resultados das avaliações realizadas pelos líderes de cada situação-problema. Observa-se que as médias que os alunos atribuíram a si mesmos (Média dos Líderes) foi próxima de 9.0 e que, na maioria das situações-problema, pouco mais de $20 \%$ do total das notas atribuídas aos pares foi abaixo de 6.0. Essa média alta da autoavaliação pode ser vista como uma supervalorização de si, ou ainda, como resultado da responsabilidade de o aluno ter assumido o papel de liderança e, por consequência, ter se dedicado mais ao trabalho que liderou.

A diversidade de amostras de desempenho pode permitir diagnosticar com alguma segurança o aprendizado do aluno, reduzindo ao máximo a possibilidade de erros, mas não há estratégia, técnica ou instrumento que garanta uma avaliação perfeita em toda a abrangência do currículo. Os alunos também realizavam uma prova individual, e a nota de cada bimestre era uma média entre as notas da prova e a nota dos trabalhos.

Os alunos promovidos são aqueles que apresentaram média aritmética igual ou superior a $6.0 \mathrm{em}$ todas as disciplinas. Aqueles alunos que tiveram uma ou duas médias abaixo de 6.0 foram promovidos pelo Conselho de Classe Escolar (órgão colegiado que delibera sobre assuntos didáticopedagógicos, incluindo a aprovação ou retenção de alunos que não atingiram os objetivos definidos). Foram considerados retidos os alunos com média abaixo de 6.0 em três ou mais disciplinas. Do total dos alunos, $67,24 \%$ foram promovidos e $32,76 \%$ ficaram retidos.

Os resultados desses alunos com retenção foram analisados, observando-se que $100 \%$ dos alunos da Turma Um tiveram melhor aproveitamento na disciplina de História, quando a nota é comparada com a média das notas das disciplinas de Português, Matemática, Geografia e Ciências. Na 
Turma Dois, apenas um aluno, dentre 13, apresentou média inferior, mas ressalta-se que a sua maior média foi na disciplina de Ciências, com nota 3.0. Na Turma Três, um aluno, dentre nove reprovados, também teve a nota de História inferior à média das demais. Essa foi a pior nota (3.5), mas a maior, na disciplina de Português (5.0), também não foi suficiente para a sua promoção. Na Turma Quatro, em um grupo de sete, um aluno também teve a média de História inferior às demais disciplinas - mas para este, em especial, a retenção se deu também pelas disciplinas de Ciências e Geografia (ele alcançou média 6.0 nas disciplinas de Português e Matemática). Dessa forma, como resultado geral, de um total de 38 alunos retidos, temos que 35 alunos apresentaram a média de História acima da média de outras disciplinas, o que equivale a $92,11 \%$. Pode-se inferir, portanto, que, para a maioria dos alunos retidos, a disciplina de História, com o uso do método ABP, não foi a principal responsável pelos resultados insatisfatórios.

Em apenas 26,32\% dos casos de retenção, a média da disciplina de História foi a maior dentre as disciplinas analisadas; logo, é possível inferir que não houve facilitação, dado que a maioria das médias está em consonância com o aproveitamento dos alunos nas demais disciplinas.

Foram verificados também os alunos promovidos pelo Conselho; em um universo de 20 alunos, $18(90 \%)$ apresentaram, na disciplina de História, média final igual ou superior a 6.0. Apenas um aluno da Turma Três e um aluno da Turma Quatro apresentaram média 5.5. Ao analisar as médias finais dos 28 alunos que apresentaram nota inferior a 6.0 em História, observou-se que apenas quatro (14,29\%) apresentaram média 6.0 em qualquer outra disciplina (Português, Matemática, Geografia e Ciências).

Vale ressaltar que $12(31,58 \%)$ dos 38 alunos que foram retidos apresentavam baixa frequência, representada por mais de $25 \%$ de faltas no ano letivo. Como a ABP é um método processual, a baixa frequência pode também prejudicar o desenvolvimento do aluno. Dos 116 alunos, 41 (35,34\%) apresentaram mais de $10 \%$ de faltas não justificadas, o que pode ser considerado um índice de baixa frequência bem elevado.

O professor demonstrou contentamento com o uso do método por sentir que este contribuiu para uma maior aproximação dele com os seus alunos. Isso permitiu que falhas de compreensão dos alunos fossem sanadas durante o processo, o que não acontecia com as aulas expositivas; também houve a percepção de algumas limitações apresentadas pelos alunos, como leitura e compreensão dos textos disponíveis no material didático.

Na perspectiva dos alunos, $49 \%$ disseram que gostaram de trabalhar com o método, $31 \%$ não tinham opinião formada e apenas $19 \%$ informaram que não gostaram de participar das aulas com o uso da ABP. Desse universo, 30\% alegaram que gostariam de ter escolhido os membros de suas equipes. Analisando as falas de alguns alunos, percebe-se que a escola investe pouco em trabalhos colaborativos; dessa forma, fica nítido o ressentimento dos alunos quanto ao trabalho em grupo. Um percentual de $72 \%$ dos alunos admitiu que a devolutiva dos trabalhos foi essencial para a compreensão dos erros que estavam sendo cometidos por eles. Apenas 16\% dos alunos assumiram que sequer se preocuparam em observar as devolutivas. É interessante pontuar que 43\% dos alunos alegaram terem sentido maior motivação em estudar, percentual muito superior aos $18 \%$ que se sentiram desmotivados. O questionário também revelou que $43 \%$ dos alunos se sentiram mais próximos do professor, embora $41 \%$ dos alunos não tenham percebido mudanças com relação à proximidade.

\section{CONSIDERAÇÕES FINAIS}

A ABP tem sido estudada em diversos países e utilizada principalmente no Ensino Superior, embora haja relatos de uso do método no Ensino Médio e algumas aplicações no Ensino Fundamental de escolas americanas. A mudança do método de ensino e de aprendizagem é trabalhosa e gera ansiedade, medo e insegurança, mas também abre oportunidades para a superação dos desafios impostos pela sociedade, em constante transformação. O método, por si só, não é suficiente para garantir melhor qualidade do ensino e da aprendizagem, mas permite que haja uma aproximação maior do professor com os seus alunos, potencializando as descobertas das dificuldades que surgem ao longo do processo e permitindo que elas sejam supridas.

Apesar de a ABP ter sido originalmente criada em uma estrutura de aprendizagem interdisciplinar e autodirigida, observa-se que pode ser utilizada com modificações, sem perder a sua essência: atividades organizadas em grupos, a partir de uma situação-problema que gere o desenvolvimento do pensamento reflexivo, a pesquisa e a troca de conhecimento e experiência entre as 
pessoas. O professor não perde o seu protagonismo, mas agregram-se a ele todos os demais participantes que apresentam democraticamente suas contribuições para a construção do conhecimento de cada estudante.

A sala de aula é um espaço de interações sociais, e a ABP privilegia trabalhos em grupos que envolvem pensar, agir e sentir, intensificando as relações entre os alunos e entre o professor e os alunos, com objetivos claros: pesquisar, debater e produzir compreensões a respeito do estudado. Pelo fato de o método estimular a pesquisa, há investimento de tempo no desenvolvimento de leituras, de registros nos relatórios, de discussões em grupo, de pesquisas, de produções de texto, de apresentações, de debates e de autoavaliações que mobilizam mais a ação do aluno, gerando compromisso e envolvimento que podem impactar diretamente na imagem que os alunos vão construindo de si mesmos como estudantes e nas relações que vão estabelecendo com os conhecimentos e com a própria aprendizagem.

O método teve o seu início com a análise do currículo de História, com o planejamento das aulas e com a criação das situações-problema. Foi importante a negociação sobre a realização de um planejamento, tanto para explicitar o que os alunos precisam saber, considerando o currículo da Rede Estadual de Ensino, quanto com relação à complexidade dos tópicos a serem abordados - mas foi importante considerar no cronograma de aulas, ainda, não somente os dias de recessos e feriados, como também as datas pré-agendadas para reuniões de conselho e reuniões de pais e mestres, com a finalidade de se ter claramente a quantidade de aulas possíveis para o desenvolvimento do trabalho com o método. Ainda se fazia necessário considerar as constantes movimentações de alunos transferidos da e para a escola, assim como entre as turmas, no início de cada ano letivo, para fechar os grupos de trabalho e dar início às atividades, seguindo as etapas do método, sem que houvesse prejuízo tanto para o trabalho pedagógico, em linhas gerais, como para o desenvolvimento do próprio método, uma vez que a base de todo o processo está no trabalho em grupo.

Foi identificado que fatores externos à sala de aula limitam os processos de ensino e de aprendizagem, como a escassez de livros e de espaços colaborativos adequados em biblioteca, que estimulam a pesquisa. A ausência de laboratório de informática inviabiliza o desenvolvimento de pesquisas científicas, com o uso da rede mundial de computadores, a digitação do texto para o Relatório Final e a criação de recursos audiovisuais para a apresentação dos alunos. A constante falta de professores e a ausência de propostas de atividades opcionais a serem realizadas pelos alunos nesses momentos trazem uma ociosidade que potencializa os conflitos, demandando tempo e energia do professor, responsável pela aula seguinte, para a mediação. Além disso, o tempo necessário para que os alunos consigam retomar o foco, a concentração e a atenção na aula é maior, reduzindo as possibilidades de aprendizagem. Destaca-se ainda que, apesar de o Conselho de Classe ser relevante por qualificar o trabalho docente e por avaliar os processos de ensino e de aprendizagem, as reuniões poderiam ser realizadas em horários alternativos, evitando-se a suspensão das aulas.

As faltas dos alunos também interferem no bom aprendizado, pois os trabalhos são processuais e colaborativos. Não basta ler as informações constantes no livro didático para se ter acesso a todo o conhecimento produzido durante a aula. Se para o aluno chegar à escola lhe é disponibilizado o transporte escolar, a interrupção do serviço acaba por inviabilizar a sua presença e, por consequência, a participação nas tarefas e nas atividades desenvolvidas em sala de aula.

Os resultados permitiram identificar que os alunos passaram a apresentar um movimento relacionado à percepção de si e do outro em relação à participação e à colaboração, o que promoveu mudanças de postura em relação ao trabalho em grupo, com indícios de mais comprometimento individual em favor do coletivo. O material empírico mostrou a participação, o envolvimento e a percepção de melhor aproveitamento dos alunos, embora tenha ficado evidente a resistência em relação à formação dos grupos de trabalho. Talvez seja importante, por se tratar de um público adolescente, que o professor crie estratégias para que a formação dos grupos aconteça de forma coletiva. Isso pode aumentar o compromisso de todos com o trabalho em grupo, inclusive desenvolvendo a reflexão e a tomada de consciência por parte dos alunos sobre as suas ações.

Ao oportunizar mais proximidade com os alunos, as suas necessidades passaram a ficar mais evidentes para o professor, possibilitando intervenções mais efetivas que os ajudassem em suas dúvidas e (in) compreensões. O método também possibilitou experiências no campo da formação humana: o professor teve como foco das preocupações o comportamento dos alunos e as relações interpessoais. 
Abriu-se espaço nas aulas para conversas e buscaram-se estratégias para que os alunos desenvolvessem outras posturas diante do trabalho em sala de aula. Para o professor que tenha o desejo de trabalhar com o método em suas aulas, recomenda-se que busque compreender as raízes filosóficas e os objetivos de cada etapa do processo, além de observar o funcionamento do método com um docente experiente. Por ser uma proposta diferente da usual, recomenda-se também que o professor desenvolva uma situaçãoproblema teste com os alunos, para que eles entendam cada uma das etapas, tenham contato com os formulários que precisarão preencher sistematicamente e compreendam o que se deseja deles.

\section{REFERÊNCIAS}

ANDRADE, Alair J. L.; CELESTE, Letícia C.; ALVES, Luciana M. Caracterização da fluência de leitura em escolares do Ensino Fundamental II. Audiology - Communication Research, São Paulo, v. 24, e1983, 2019.

ARAÚJO, Ulisses F.; SASTRE, Genoveva. Aprendizagem Baseada em Problemas no Ensino Superior. São Paulo: Summus, 2009.

BARELL, John. Problem-based learning: an inquiry approach. Arlington Heighs: SkyLight, 1998.

BANDEIRA, Hilda M. M. Pesquisa Colaborativa: unidade pesquisa-formação. In: IBIAPINA, Ivana M. L. de M.; BANDEIRA, Hilda M. M.; ARAUJO, Francisco A. M. (orgs.). Pesquisa Colaborativa: multirreferenciais e práticas convergentes. Teresina: EDUFPI, 2016. p. 63-74.

BONALS, Joan. O trabalho em pequenos grupos na sala de aula. São Paulo: Artmed, 2003.

BOUD, David; FELETTI, Grahame. The challenge of problem-based learning. 2. ed. London: Kogan Page Limited, 1999.

BRASIL. Lei No 4.024, de 20 de dezembro de 1961. Fixa as Diretrizes e Bases da Educação Nacional. Diário Oficial da União: seção 1, Brasília, DF, p. 11.429, 27 dez. 1961.

BRASIL. Ministério da Educação. Base Nacional Comum Curricular. 2018. Disponível em: http://basenacionalcomum.mec.gov.br. Acesso em: 2 nov. 2018.

DUARTE, Newton. O debate contemporâneo das teorias pedagógicas In: MARTINS, Lígia M.; DUARTE, Newton (orgs.). Formação de professores: limites contemporâneos e alternativas necessárias [online]. São Paulo: Editora UNESP; São Paulo: Cultura Acadêmica, 2010. p. 33-50.

DUCH, Barbara J.; GROH, Susan E.; ALLEN, Deborah E. The power of Problem-Based Learning. Stylus: Sterling, 2001.

GODOY, Arilda S. Revendo a aula expositiva. In: MOREIRA, Daniel A. (org.). Didática do ensino superior: técnicas e tendências. São Paulo: Pioneira, 2000. p. 75-82.

IBIAPINA, Ivana M. L. M. Pesquisa Colaborativa: Investigação, formação e produção de conhecimentos. Brasília: Liber Livro, 2008.

IBIAPINA, Ivana M. L. M. Reflexões sobre a produção do campo teórico-metodológico das pesquisas colaborativas: gênese e expansão. In: IBIAPINA, Ivana M. L. de M.; BANDEIRA, Hilda M. M.; ARAUJO, Francisco A. M. (orgs.). Pesquisa Colaborativa: multirreferenciais e práticas convergentes. Teresina: EDUFPI, 2016. p. 33-62.

IBIAPINA, Ivana M. L. M.; BANDEIRA, Hilda M. M. Pesquisar-formar em colaboração: compartilhamento teórico-prático das vivências do Formar. In: IBIAPINA, Ivana M. L. M.; 
BANDEIRA, Hilda M. M. Formação de Professores na perspectiva histórico-cultural: vivências no formar. Teresina: EDUFPI, 2017. p. 35-55.

KELSON, Ann C. M.; DISTLEHORST, Linda H. Groups in Problem-Based Learning (PBL): essential elements in theory and practice. In: EVENSEN, Dorothy H.; HMELO, Cindy E. (eds.). Problem Based Learning: a research perspective on learning interactions. New Jersey: Lawrence Erlbaum Associates, 2000. p. 167-184.

LAMBROS, Ann. Problem-Based Learning in Middle and High School Classrooms: A Teacher's Guide to Implementation. Thousand Oaks: Corwin Press, 2004.

LUCKESI, Cipriano C. Avaliação de aprendizagem: componente do ato pedagógico. São Paulo: Cortez, 2011.

LOURENÇO, Rosemeire S.; PALMA, Ângela P. T. V. O conflito cognitivo como princípio pedagógico no processo ensino-aprendizagem nas aulas de educação física. Revista de Educação do Cogeime, Ano 14, n. 27, dez/2005. p. 43-54.

MAMEDE, Silvia. Aprendizagem baseada em problemas: características, processos e racionalidade. In: MAMEDE, Silvia; PENAFORTE, Júlio César (orgs.). Aprendizagem Baseada em Problemas: anatomia de uma nova abordagem educacional. Fortaleza: Hucitec, 2001. p. 25-48.

MARTINS, Daiana B.; ESPEJO, Márcia M. S. B. Problem Based Learning - PBL no ensino de contabilidade: guia orientativo para professores e estudantes da nova geração. São Paulo: Atlas, 2015.

MASETTO, Marcos T. Inovação na aula universitária: espaço de pesquisa, construção de conhecimento interdisciplinar, espaço de aprendizagem e tecnologias de comunicação. Perspectiva, Florianópolis, v. 29, n. 2, p. 597-620, jul./dez. 2011.

MUNHOZ, Antônio. ABP - Aprendizagem Baseada em Problemas em ambientes virtuais de aprendizagem: Ferramenta de apoio ao docente no processo de ensino e aprendizagem. São Paulo: Cengage, 2015.

NÉRICI, Imídeo G. Didática do ensino superior. São Paulo: Ibrasa, 1993.

O MANIFESTO dos Pioneiros da Educação Nova. Revista HISTEDBR On-line, Campinas, n. especial, p.188-204, ago. 2006.

OLIVEIRA, Evaneide B. Aprendizado Baseado em Problemas (Problem-Based Learning): a sua importância no ensino da Contabilidade. 2010. 146 f. Dissertação (Mestrado em Ciências Contábeis e Financeiras), Pontifícia Universidade Católica de São Paulo, São Paulo, 2010.

OLIVEIRA, Wellington. Encontros colaborativos: procedimentos metodológicos para o trabalho de pesquisa entre designers e usuários. In: IBIAPINA, Ivana M. L. M.; BANDEIRA, Hilda M. M. Formação de Professores na perspectiva bistórico-cultural: vivências no formar. Teresina: EDUFPI, 2017. p. 7996.

PARK, Sung H. Impact of Problem-Based Learning (PBL) on teachers' beliefs regarding technology use. 2006. Tese (Doutorado em Filosofia) - Faculty of Purdue University, West Lafayette, 2006.

PENAFORTE, Júlio César. John Dewey e as raízes filosóficas da Aprendizagem Baseada em Problemas. In: MAMEDE, Silvia; PENAFORTE, Júlio César. (orgs.). Aprendiragem Baseada em Problemas: anatomia de uma nova abordagem educacional. Fortaleza: Hucitec, 2001. p. 25-48. 
POZO, Juan I. Aprendizes e mestres: A nova cultura da aprendizagem. Porto Alegre: Artmed, 2002.

RIBEIRO, Luis R. C. A aprendizagem baseada em problemas (PBL): uma implementação na educação em engenharia na voz dos autores. 2005. 209 f. Tese (Doutorado em Educação) - Universidade Federal de São Carlos, São Carlos, 2005.

RIBEIRO, Luis R. C. Aprendizado Baseado em Problemas. São Carlos: UFSCAR - Fundação de Apoio Institucional, 2008.

SÁ, Henrique L.C. Análise crítica da aprendizagem baseada em problemas. In: MAMEDE, Sílvia; PENAFORTE, Júlio César. (Orgs.). Aprendizagem baseada em problemas: anatomia de uma nova abordagem educacional. Fortleza: Hucitec, 2001. p. 203-213.

SAVIANI, Dermeval. História das ideias pedagógicas no Brasil. 3. ed. rev. Campinas: Autores Associados, 2010.

SAVIN-BADEN, Maggi; MAJOR, Claire H. Foundations of Problem-Based Learning. Maidenhead: Open University Press, 2004.

SCHNEUWLY, Bernard; DOLZ, Joaquim (orgs.). Gêneros orais e escritos na escola. Campinas. Mercado de Letras, 2013.

TOMAZ, José B. O papel e as características do professor. In: MAMEDE, Silvia; PENAFORTE, Júlio César (Orgs.). Aprendizagem Baseada em Problemas: anatomia de uma nova abordagem educacional.

Fortaleza: Hucitec, 2001. p. 25-48.

VEIGA, Ilma P. A. (org.). Formação médica: aprendizagem baseada em problemas. Campinas: Editora Papirus, 2015.

WOOD, Diana. ABC of learning and teaching in medicine: Problem-based learning. British Medical Journal, 2003.

Submetido: $17 / 05 / 2020$

Aprovado: 21/12/2020 